\title{
Membraneless Plant Microbial Fuel Cell using Water Hyacinth (Eichhornia crassipes) for Green Energy Generation and Biomass Production
}

\author{
Ika Dyah Widharyantia,*, Muhammad Andiri Hendrawanª, Marcelinus \\ Christwardana ${ }^{\mathrm{b}, * *}$
}

\author{
aDepartment of Chemical Engineering, Pertamina University, Jl. Teuku Nyak Arief, Simprug, Jakarta, 12220, Indonesia \\ ${ }^{b}$ Department of Chemical Engineering, Institut Teknologi Indonesia, Jl. Raya Puspitek Serpong, South Tangerang, Banten, 15320, \\ Indonesia
}

\begin{abstract}
The plant microbial fuel cell (PMFC) is a technology built to produce renewable and sustainable electricity in order to meet the increasing global demand. This study demonstrates the potential application of PMFC in swamps dominated by water hyacinth to produce biological energy and plant biomass. In this research, the plant was integrated into a microbial fuel cell that adopts various types of anode materials such as carbon felt, iron and zinc, with a varying distance of 10 and $20 \mathrm{~cm}$ between the anode and cathode. Organic compounds emerging from the photosynthesis process were deposited by plant roots, which were then oxidized by bacteria in the mud media. The result showed that the developed PMFC produced a voltage and current density of $244.8 \mathrm{mV}$ and $185.4 \mathrm{~mA} / \mathrm{m}^{2}$, respectively, for 30 days, with a maximum power of $100.2 \mathrm{~mW} / \mathrm{m}^{2}$ in the cells using zinc as anode material with an electrode spacing of $10 \mathrm{~cm}$. Furthermore, the $\mathrm{pH}$ value on PMFC with a longer electrode was higher than the shorter distance due to the protons' inability to move from anode to cathode against the force of gravity. In conclusion, PMFC which utilizes water hyacinth has a good performance in converting chemical energy from the substrate into electrical energy, and has the potential to be developed in underdeveloped areas.
\end{abstract}

Keywords: Plant Microbial Fuel Cell, Renewable energy, Bioelectricity, Membraneless, Swamp

Article History: Received: $23^{\text {rd }}$ August 2020; Revised: $30^{\text {th }}$ September 2020; Accepted: $9^{\text {th }}$ October 2020; Available online: $12^{\text {th }}$ October 2020 How to Cite This Article: Widharyanti, I.D., Hendrawan, M.A., Christwardana, M. (2021). Membraneless Plant Microbial Fuel Cell using Water Hyacinth (Eichhornia crassipes) for Green Energy Generation and Biomass Production. Int. Journal of Renewable Energy Development, 10(1), 7178

https://doi.org/10.14710/ijred.2021.32403

\section{Introduction}

Presently, energy is one of the necessities of life due to its ability to support numerous human activities. Fossil fuels, including oil, gas, and coal, are still the primary sources of electrical energy. According to Bimanatya \& Widodo (2018), the projected use of fossil energy in Indonesia by 2025 is approximately $121,792.33$ kilotons. Therefore, its unsustainability needs to be a great concern because the amount keeps decreasing due to the increase in consumption of these non-renewable sources of energy. Besides, these primary fuel sources lead to various adverse effects on the environment, such as global warming (Lott et al., 2017). For example, coal is a type of fossil energy with the highest emitters of $\mathrm{CO}_{2}$, which has a significant contribution to the increasing global temperature (Shahbaz et al., 2013; Hadi et al., 2005). Therefore, these reasons led to the studies on alternative energy sources, which are expected to be used as substitutes for fossil fuels in the future. One alternative means of energy currently being researched globally is fuel cells, which is classified as environmentally friendly due to its inability to produce pollutants like conventional fuel.

The fuel cell is an electrochemical-based technology that can produce energy in the form of direct current electricity using biological matters as their catalysts, therefore it is also known as Biological Fuel Cells (BFC). An example is the Plant Microbial Fuel Cell (PMFC), one of the alternative energy developments that are unique and interesting because it utilizes plants as a cultivation medium of microorganisms, where they act as biocatalysts. The microorganisms surrounding the roots of plants tend to convert the organic material not absorbed by plants during photosynthesis, into electrons and protons, which are then converted to electric current (Helder et al., 2012,2013). Furthermore, the plants used in PMFC are useful for reducing $\mathrm{CO}_{2}$ emissions by converting them to biomass through photosynthesis. This process is one of the methods used to produce alternative energy without releasing harmful compounds to the environment. It also acts as a solution to the prolonged environmental problems due to the use of fossil fuels

\footnotetext{
* Corresponding author: ika.widharyanti@universitaspertamina.ac.id /**marcelinus@iti.ac.id
} 
Citation: Widharyanti, I.D., Hendrawan, M.A., Christwardana, M. (2021). Membraneless Plant Microbial Fuel Cell using Water Hyacinth (Eichhornia crassipes) for Green Energy Generation and Biomass Production. Int. Journal of Renewable Energy Development, 10(1), 71-78, doi: 10.14710/ijred.2021.32403

P a g e 72

(Wilberforce et al., 2017). However, PMFC cannot totally substitute the commercial use of fossil energy because the amount of energy produced is relatively low to support human life. This is because the rate of electron transfer from microorganisms to the electrode surface is still slow, where the conductivity and chemical content contained in the soil or mud acts as a planting medium that influences the rate of electron transfer (Aghababaie et al., 2015; Prasad and Tripathi, 2018).

The plant type is one of the factors that influence PMFC due to the different amount of electrical current produced by each plant. Some types of microorganisms are only found in certain plant roots or media. In general, the types of plants commonly used in PMFCs to produce more electricity are those that live in water due to their electrolyte capability (Wetser et al., 2016). Some types of plants commonly used are Spartina anglica, Phragmites australis, and Eichhornia crassipes (Timmers et al., 2010; Wetser et al., 2015; Di et al., 2020; Zhou et al., 2018; Gaurav et al., 2020). Eichhornia crassipes or water hyacinth is commonly used due to its numerous advantages, such as being readily obtained, easily cultivated, ability to grow in water and wetlands, thereby making it useable for bioremediation (Pamintuan et al., 2018). In addition, water hyacinth plants are often regarded as weeds in some regions due to their rapid growth and are widely used to decompose water polluted with heavy-metal waste (Gaurav et al., 2020).

Electrodes are one of the other factors that influence the final result of PMFC, in terms of type, shape, and distance. The type of electrode commonly used is carbonbased due to its high conductivity and suitable surface properties in biofilms development and because the price is relatively cheaper than metal-based electrodes (Liu, 2008; Dubei and Guruviah, 2019; Zhang and Zhao, 2009). However, further treatments are needed to increase their electrical conductivity and support the electron transfer process. Metal-based electrodes can be used as long as they are not corrosive and not toxic to microorganisms.

This study aims to determine the effect of the anode material and its electrode distance from the cathode on the electricity produced by PMFC. The plant used was water hyacinth, which is found in numerous regions in Indonesia. The analysis includes measuring the amount of current density and cell potential generated daily in the same environmental conditions, as well as monitoring the growth of biomass, based on the number of the stem. Furthermore, polarization and power curves are measured to determine the potential power generated at PMFC.

\section{Materials and Methods}

\subsection{PMFC configuration and operation}

PMFC consists of a cathode and anode inseparable by a membrane and its configuration, as shown in Figure 1a. The cathode consists of graphite carbon felt, while the anode is varied using several types of material, namely commercial graphite carbon felt, copper, or zinc found in Jakarta, Indonesia. Initially, the anode was first treated with $1 \mathrm{M} \mathrm{HCl}$ and $1 \mathrm{M} \mathrm{NaOH}$ in order to increase its conductivity (Sigma Aldrich, St. Louis, USA). The copper wire that acted as the current collector was then bonded to the anode and the cathode.
Table 1

Sample naming for six various PMFCs

\begin{tabular}{lcc} 
Sample Name & $\begin{array}{c}\text { Anode } \\
\text { Material }\end{array}$ & Electrode distance (cm) \\
\hline PMFC-1 & Carbon felt & 10 \\
PMFC-2 & Carbon felt & 20 \\
PMFC-3 & Iron & 10 \\
PMFC-4 & Iron & 20 \\
PMFC-5 & Zinc & 10 \\
PMFC-6 & Zinc & 20 \\
\hline
\end{tabular}
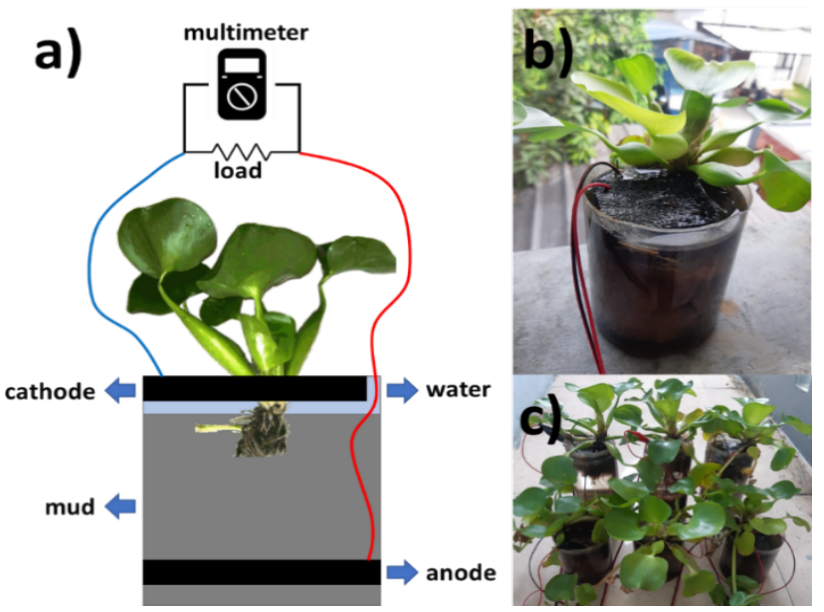

Fig. 1 a) Schematic illustration and b) photograph of PMFC adopting water hyacinth, and c) the total six samples of PMFC.

The distance between the anode and the cathode varied from 10 and $20 \mathrm{~cm}$, thereby making it possible to study the electrode gradient effect on the harvested energy. The water hyacinth used in this study was obtained from the plant market in Jakarta, Indonesia, and acclimatized for 7 days. One cluster of Eichhornia crassipes comprises approximately 6 stems, and all plants in PMFC are sprayed daily from above using demineralized water. The mixing solution, consisting of tap water and mud, acted as anolyte and was used to grow electrochemical active biofilms at the PMFC anode, as shown in Figure $1 \mathrm{~b}$. Furthermore, PMFC incubation was carried out for 30 days in an open area of the balcony at a temperature range of $25-31{ }^{\circ} \mathrm{C}, 81 \pm 10 \%$ relative humidity, $3324 \pm 783$ lux light intensity, and an illumination period of 12 hours a day. Six PMFC combinations were used in this study, as shown in Figure 1c and Table 1.

\subsection{Analysis of $p H$, plant growth, and electrochemical characterization}

Approximately $4 \mathrm{~mL}$ of anolyte was taken every 3 days to measure the $\mathrm{pH}$ value. Furthermore, the number of water hyacinth stem was measured every 4 days with a ruler used to determine the growth of plant biomass. The dry biomass at the beginning and end of the MFC process is measured to confirm the growth of water hyacinth. PMFC incubation was carried out on a closed circuit, with external resistance of $1000 \Omega$. Potentials and current densities in PMFC were manually measured from beginning to the end of the incubation process (30 days) using a digital multimeter Muxindo DT830B. Polarization 
curves were measured on the $30^{\text {th }}$ day to determine Maximum Power Density (MPD) by varying external resistance, which was manually applied, and measured every $15 \mathrm{~min}$ from OCV (open cell voltage) to subsequently $1 \mathrm{M} \Omega, 100 \mathrm{~K} \Omega, 10 \mathrm{~K} \Omega, 1 \mathrm{~K} \Omega, 100 \Omega$, and $10 \Omega$.

\section{Results and Discussion}

\subsection{Effect of Anode Materials}

The trends of current density and voltage generated in the PMFC study are illustrated in Figure 2. Figure 2a shows the fluctuating current density values from day 0 to 16 , which started stabilizing from the $16^{\text {th }}$ to the $30^{\text {th }}$ day. PMFC-5 with zinc anode material had the highest average value of current density at a stable condition of 185.4 $\mathrm{mA} / \mathrm{m}^{2}$. The PMFC-3 follows this with an iron anode, which had an average current density value of 141.1 $\mathrm{mA} / \mathrm{m}^{2}$. Finally, the PMFC- 1 with electrodes made of carbon felt had the lowest value at $26.0 \mathrm{~mA} / \mathrm{m}^{2}$. Voltage values also have the same trend as current density, where PMFC fluctuated from day 0 to day 16 and started stabilizing from the $16^{\text {th }}$ to $30^{\text {th }}$ day, as shown in Figure 2b. Similar to the current density results, PMFC-5 led to the highest average voltage value at the stable condition of $244.8 \mathrm{mV}$, followed by PMFC-3, which had an average voltage value in stable conditions of $152.2 \mathrm{mV}$ and PMFC1 with the lowest average voltage at $79.6 \mathrm{mV}$.
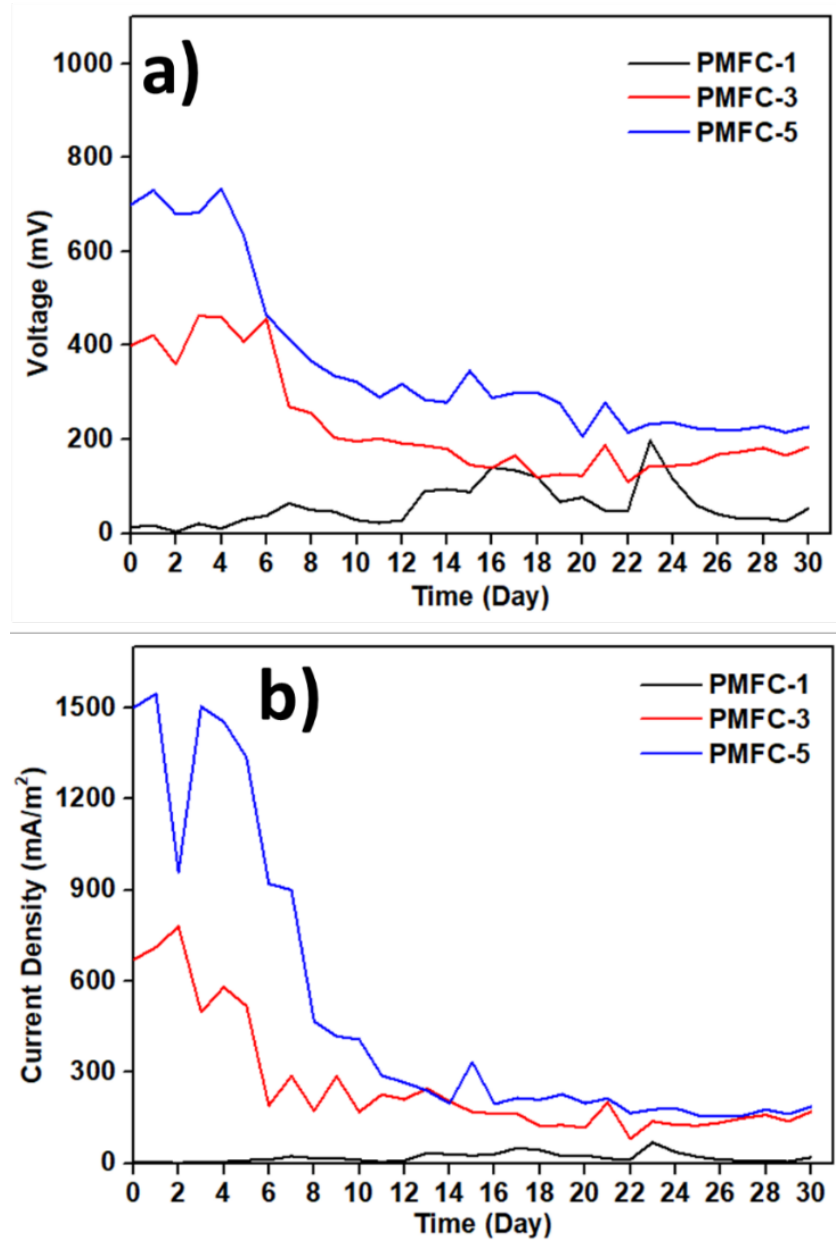

Fig. 2 a)Voltage and b) current density of PMFC in various anode materials.
From Fig.2, it can be concluded that the differences in anode material play a role in producing electricity. This is due to several factors, including the standard reduction potential value of metal-based materials, the zeta potential of non-metal-based materials (carbon-felt), the metal's electrical conductivity, and the resistivity value of each material. Based on the standard reduction potential value, zinc metal is the smallest at $-0.77 \mathrm{~V}$, followed by iron with $-0.44 \mathrm{~V}$ for $\mathrm{Fe}^{2+}$ and $+0.77 \mathrm{~V}$ for $\mathrm{Fe}^{3+}$ (Reddy, 2011). The smaller the potential value of reduction standards, the more difficult it takes the metal to reduce (Bhatt, 2016). Therefore, zinc cathode has high reducing properties, therefore, the reduction of power is higher when compared to iron. The carbon felt electrode has a zeta potential value close to zero at neutral $\mathrm{pH}$ conditions and ambient temperature (Park et al., 2014). The higher the zeta potential value (negative or positive), the bigger the magnitude of a particle's electrostatic rejection force (Lu \& Gao, 2010). Furthermore, the zeta potential value is directly proportional to the electrical conductivity (Novikov et al., 2015). Therefore, the near-zero zeta potential value of a material indicates its poor ability to conduct electricity.

Zinc and iron have electrical conductivity values of $1.69 \times 10^{7} \mathrm{~S} / \mathrm{m}$ and $1 \times 10^{7} \mathrm{~S} / \mathrm{m}$, respectively (ASM International, 1990). Therefore, it can be concluded that the cathode with zinc material is better at conducting electric charge than iron and carbon felt. Another factor capable of affecting PMFC is electrical resistivity, which is the amount of resistance to a material's electric current. Carbon felt has the highest electrical resistivity value of approximately 0.03 S.m (Md Khudzari et al., 2019), followed by iron at $1 \times 10^{-7} \Omega . \mathrm{m}$, and zinc as the lowest with a value of $5.9 \times 10^{-8} \Omega . m$ (ASM International, 1990). The lower the electrical resistivity value indicates a decrease in resistance to electric current.

Figures 2a-b also shows the current density trend and the potential difference that tends to fall from the start to the end of the research. However, there are fluctuations in output on certain days. The decrease in voltage and current density is due to the influence of microorganisms around the plant roots, which are at the adaptation stage. After 16 days, the microorganisms enter the growth phase and are stationary, therefore, the voltage and current density values become more stable, with little fluctuation. These microorganisms act as biocatalysts in degrading organic material into electrons and protons. The decreases in the number of microorganisms that live around the roots of plants tend to affect the current density and voltage values of the PMFC.

In general, the microorganism has 4 life phases, namely the lag, exponential, stationary, and death. The process starts with a lag phase where the microorganisms are in the adaptation stage of the media. The graph shows the effect when the lag phase is marked by a decrease in current density and voltage value. This phase tends to affect the anode and cathode's potential, thereby decreasing the value of current density and voltage. Furthermore, there is an exponential phase with massive duplication of microorganism division. Therefore, based on the graph of the resulting current strength, the value tends to decrease. At the stationary and death phases, the number of microorganism and duplications are similar. Both phases are characterized by the current density and voltage values, which are stable from the $16^{\text {th }}$ to the $30^{\text {th }}$ day. Furthermore, there is a death phase where many 
Citation: Widharyanti, I.D., Hendrawan, M.A., Christwardana, M. (2021). Membraneless Plant Microbial Fuel Cell using Water Hyacinth (Eichhornia crassipes) for Green Energy Generation and Biomass Production. Int. Journal of Renewable Energy Development, 10(1), 71-78, doi: 10.14710/ijred.2021.32403

$\mathrm{P}$ a g e 174

microorganisms die due to several factors, such as the depletion of nutrients and the formation of metabolites that inhibit growth. The research period of 30 days shows that microorganisms' conditions have not entered the phase of death because the substrate, which is a source of nutrition for microorganisms, is continuously supplied through the photosynthesis process.

\subsection{Effect of Electrodes Distance}

The distance between the electrodes (anode and cathode) varied from 10 to $20 \mathrm{~cm}$. The observed current density and voltage values of each applied distance are shown in Figure 3. Similar to the effect of variations in the type of electrode, it can be seen that the current density value fluctuated from day 0 to 16 . However, from the $16^{\text {th }}$ to $30^{\text {th }}$ day, the current density values obtained started stabilizing, as shown in Figure 3a. PMFC-1, with an average current density value in stable conditions of 26.0 $\mathrm{mA} / \mathrm{m}^{2}$, had a higher value than PMFC-2, with an average current density value in stable conditions of $13.0 \mathrm{~mA} / \mathrm{m}^{2}$. Meanwhile, PMFC-3 had an average current density value in stable conditions of $141.1 \mathrm{~mA} / \mathrm{m}^{2}$, higher than PMFC-4 at $108.6 \mathrm{~mA} / \mathrm{m}^{2}$. PMFC-5 produced an average current density value in stable conditions of $185.4 \mathrm{~mA} / \mathrm{m}^{2}$, higher than PMFC-6, at $147.5 \mathrm{~mA} / \mathrm{m}^{2}$. Figure $3 \mathrm{~b}$ shows the fluctuating voltage value on day 0 to 16 , which started stabilizing on the $16^{\text {th }}$ to $30^{\text {th }}$ day. PMFC- 1 and PMFC-2 yielded average voltage values under stable conditions of $79.6 \mathrm{mV}$ and $41.1 \mathrm{mV}$, respectively.
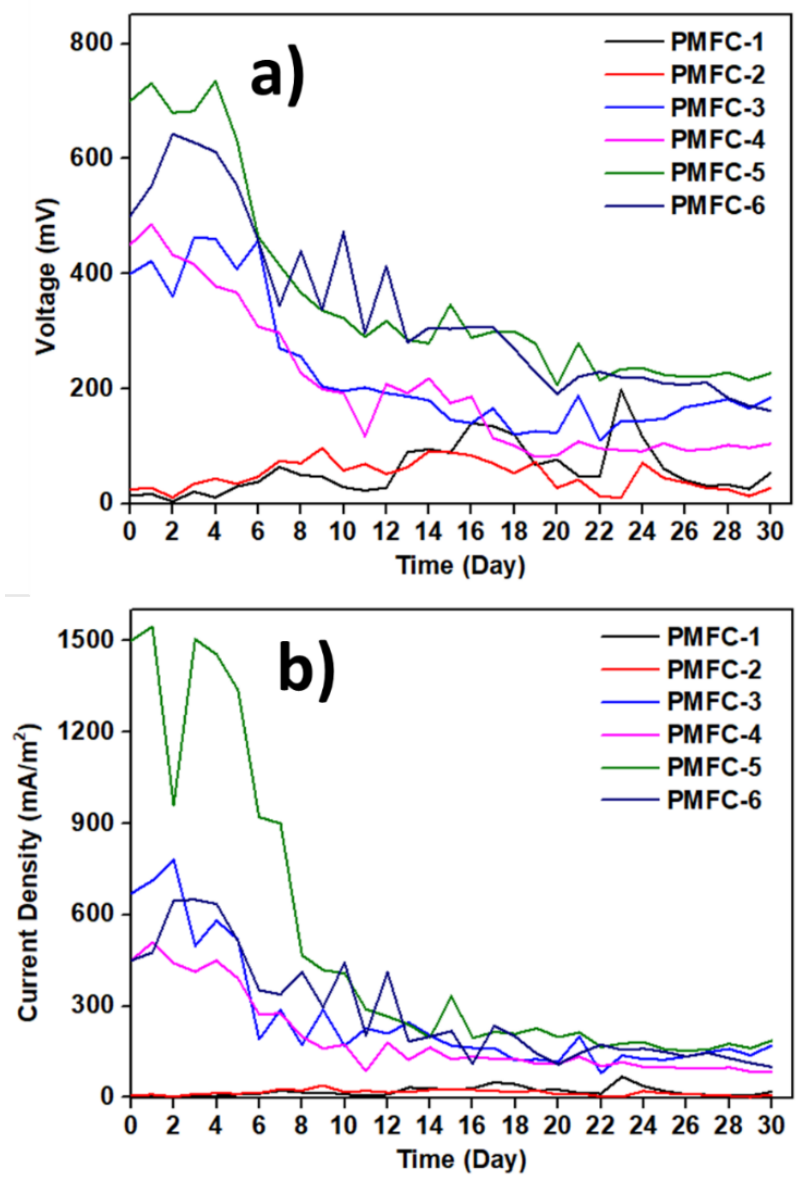

Fig. 3 a) Voltage and b) current density of PMFC in various electrode spaces.
Meanwhile, PMFC-3 and PMFC-4 obtained average voltage values at stable conditions of $152.2 \mathrm{mV}$ and 103.3 $\mathrm{mV}$, respectively. At the same time, PMFC-5 and PMFC-6 produced average voltage values at stable conditions of $244.8 \mathrm{mV}$ and $222.3 \mathrm{mV}$.

The average values of current density and voltage obtained show that PMFC has the same material, at a distance of $10 \mathrm{~cm}$, between the electrodes compared to 20 $\mathrm{cm}$. This is because in PMFC with a longer distance, the protons generated at the anode (PMFC reactor base) need to travel a longer distance to reach the cathode surface (Sangeetha \& Muthukumar, 2013). In an effort to reach the cathode, the protons need to face an obstacle in the form of gravitational force that hinders the displacement process from the anode part. Therefore, in PMFC with a farther distance, there is a higher possibility for the proton's inability to reach the cathode to undergo a reduction process with oxygen.

\subsection{Polarization and Power Curves}

Furthermore, the maximum power density was measured by varying the external resistors used on day 30, as shown in Figure 4. An external resistor was applied to each PMFC and allowed to stand for approximately 15 minutes to reach a pseudo-steady-state condition. From the resistor's external variation, a polarization curve is obtained, which displays the voltage value as a function of current density, as shown in Figure 4a.
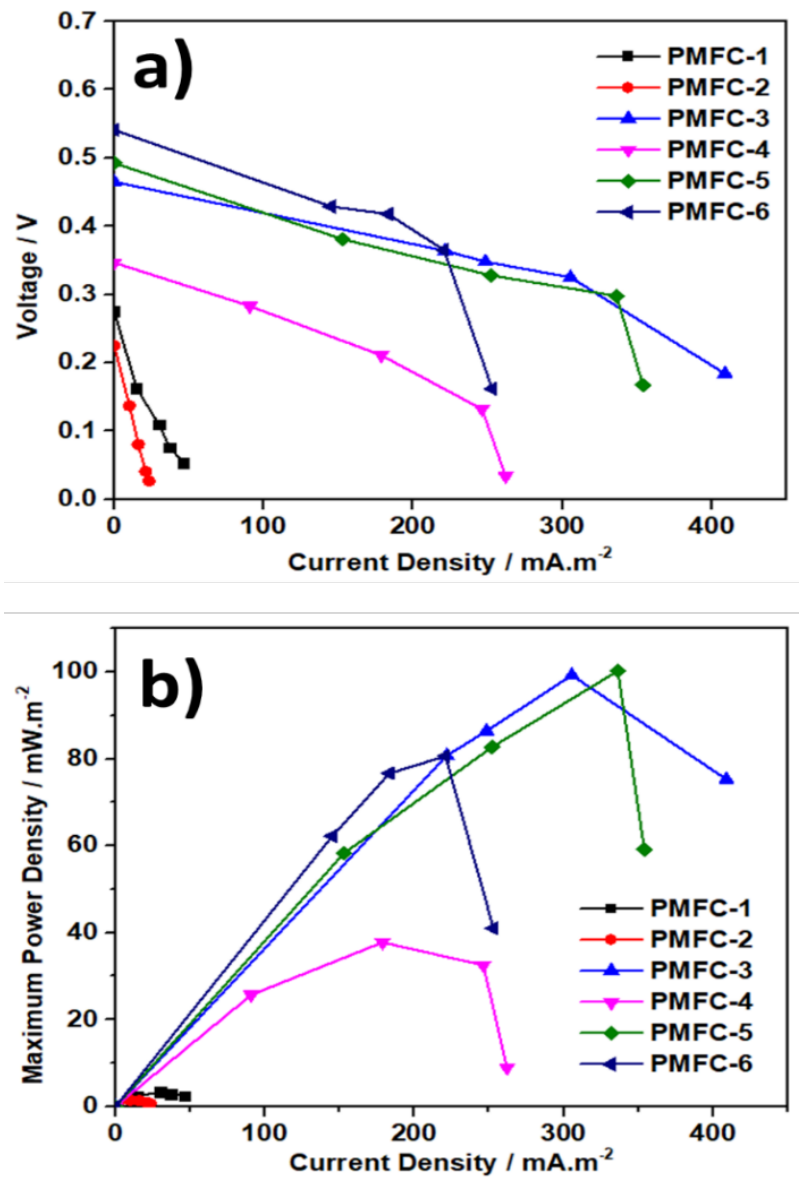

Fig. 4 a) Polarization and b) power curves of PMFC adopting water hyacinth 
Table 2

Maximum Power Density Comparison with other works

\begin{tabular}{|c|c|c|c|c|}
\hline Anode & Cathode & Plant & MPD $\left(\mathrm{mW} / \mathrm{m}^{2}\right)$ & Ref. \\
\hline Graphite & Graphite & Chlorophytum comosum & 18 & Azri et al., 2018 \\
\hline Carbon fiber brush & Carbon fiber cloth & Epipremnum aureum & 15.38 & Sarma and Mohanty, 2018 \\
\hline Copper plate & Copper plate & Chlorophytum inornatum & 10 & Kudke et al., 2017 \\
\hline Carbon fiber textile & Carbon fiber textile & $\begin{array}{l}\text { Agapanthus } \\
\text { africanus }\end{array}$ & 15.55 & Gómora-Hernández et al., 2019 \\
\hline Zinc plate & Carbon felt & Eichhornia crassipes & 100.2 & This work \\
\hline
\end{tabular}

In that graph, the polarization curve is divided into three parts: (i) the OCV (Open Circuit Voltage) zone where there is no current, (ii) the zone where the voltage value starts to decrease linearly with a rise in current density value, (iii) zone where there is a drastic decrease in the value of the voltage at the higher current density values (Logan et al., 2006). Figure 4a show that PMFC-1, PMFC-2, PMFC3 , and PMFC-4 had OCV values of $0.275 \mathrm{~V}, 0.225 \mathrm{~V}, 0.465$ $\mathrm{V}$ and $0.347 \mathrm{~V}$. Meanwhile, PMFC-5 and PMFC- 6 which use zinc anodes had OCV values of $0.493 \mathrm{~V}$ and $0.542 \mathrm{~V}$, respectively.

The cathode material variation shows that PMFC with zinc material produces the highest voltage value at $\mathrm{OCV}$, followed by iron and carbon felt. Based on the electrodes distance variation, the closer distance between electrodes resulted in higher OCV values than PMFC with a longer distance. However, this was inapplicable to PMFCs with zinc anode material where the OCV value with closer distance lowered the value. This is also influenced by the activity of microorganisms, thereby affecting the value of OCV.

Figure $4 \mathrm{~b}$ is a power curve showing the maximum density of each PMFC. The figure shows that PMFC-1, PMFC-2, PMFC-3, PMFC-4, PMFC-5 and PMFC-6 had maximum power density values of $3.29,1.39,99.26,37.73$, 100.2 and $80.64 \mathrm{~mW} / \mathrm{m}^{2}$, respectively. Based on the variation of the electrodes distance, PMFC with iron, zinc, and carbon material felt had closer distance, which led to a higher maximum power density value. Furthermore, the anode material variation shows that PMFC with zinc material produced a higher MPD value than iron or carbon felt. Table 2 shows the comparison of MPD in this research and previous studies. It indicates that this study's MPD is higher than others, which means that PMFC has the potency to be scaled-up in the future.

\subsection{Trend of $p H$}

Figure 5 shows the trend of $\mathrm{pH}$ values during the incubation process of each PMFC using the same anode material. From this graph, PMFC-1 produces a higher $\mathrm{pH}$ value than PMFC-2 with a longer distance. The same phenomenon is also seen at PMFC-3, which can produce a higher $\mathrm{pH}$ value than PMF-4 with a longer distance. The PMFC with a longer distance enables the protons to move from the anode to the cathode. Therefore, there is a possibility that more protons are dissolved in the electrolyte due to the driving force in the form of a gravitational force that blocks its movement. According to the Bronsted-Lowry theory, acids are proton donors
(Kauffrnan, 1988), therefore a greater accumulation in the media results in more acidic $\mathrm{pH}$ (Christwardana et al., 2020). In general, the following conditions are also seen on the PMFC $\mathrm{pH}$ chart of a zinc anode. However, in the last few days, PMFC-6 produced an electrode distance with a higher $\mathrm{pH}$ value than PMFC-5 at a closer electrode distance. This is due to the ability of a plant to change the surrounding $\mathrm{pH}$ to be more acidic by releasing protons or more alkaline with the release of hydroxyl ions through the roots (Neina, 2019). However, the activity of microorganisms on plant roots is the most influential, which tends to increase the $\mathrm{pH}$ value of substrate rather than decrease the value.

\subsection{Biomass Production}

Biomass analysis was carried out by counting the number of plants stems at the time of the initial and final research, every four days.

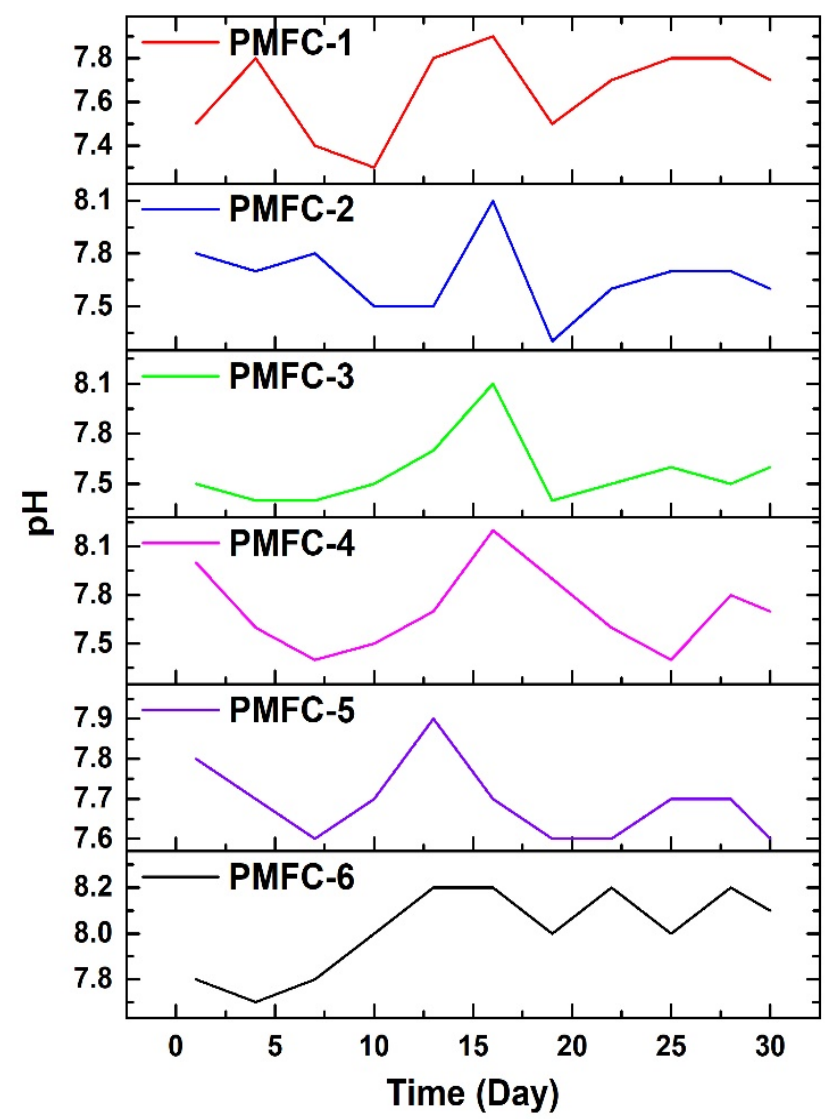

Fig. $5 \mathrm{pH}$ profile of $\mathrm{PMFC}$ adopting water hyacinth during the incubation period for 30 days 
It was also carried out by measuring the initial and final dry weight of plant biomass. The number of stems growing from each PMFC is shown in Figure 6a. From the figure, it can be seen that each PMFC started with the same number of six stems. Furthermore, there was an increase in the number of stems over time until the last day of the study, ranging from 10 to 13 for each water hyacinth plant. This indicates that the plant grows with an increase in the number of stems, with a dry weight of biomass at the initial and final day of incubation for each plant used as a growth medium as shown in Figure 6b. From the following values, the increase in dry weight of biomass indicates that the plant is experiencing growth.

From the two observational data above, it is concluded that these plants experience growth every day, consequently, they need nutrients. In nutritional sufficiency, plants carry out photosynthesis, with the produced glucose distributed to other plant parts through the phloem tissue. The excess glucose not used by plants becomes wasted through its roots (Koo et al., 2005). Glucose, as one of the wasted organic materials, is used by microorganisms around plant roots and degraded into protons, electrons, and $\mathrm{CO}_{2}$, which are used to produce electrical energy in PMFC technology.
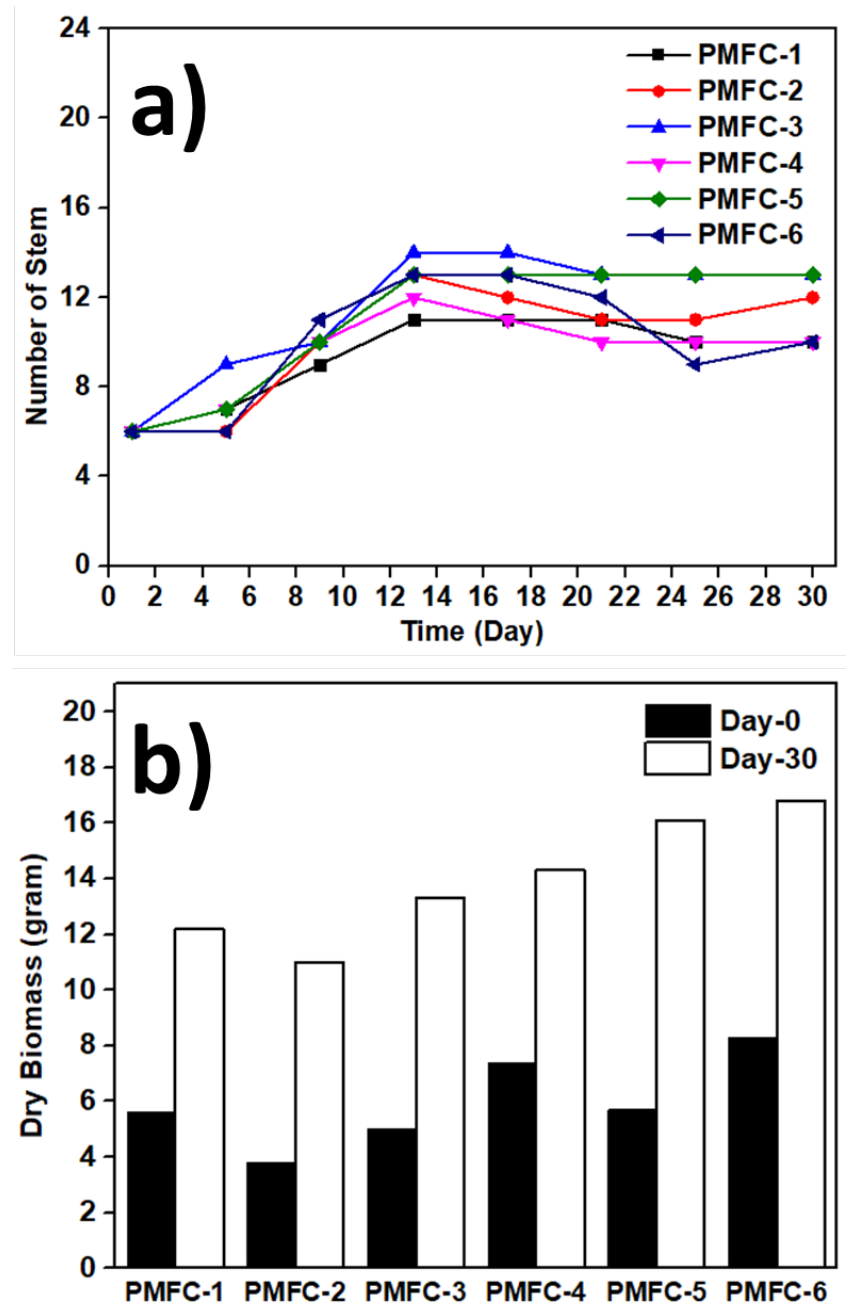

Fig. 6 a) Stem growth and b) dry biomass of water hyacinth.

\subsection{Limitations and Future Prospects}

Several studies are currently conducted on PMFC. However, the electric current output obtained is still relatively minimal, therefore, it cannot be compared with other renewable energy sources. The limitations associated with this study are the use of carbon felt, ferrum plate, and zinc plate as electrodes. According to Takanezawa et al. (2010), a platinum catalyst is a noble metal and electrode material capable of affecting the power output of PMFC. In addition, the study is also limited to the use of tubular reactor design. Helder et al. (2012) stated that a flat plate PMFC reactor's design can increase the power output obtained from a PMFC. Other factors capable of affecting the performance include weather and the microorganism community. Efforts to make the performance free from weather effects can be carried out by increasing the insulation on its electrode (Helder et al. 2013). The microorganism community's role in degrading organic material into electrical energy can be carried out by isolating and characterizing the electrochemical properties of these microorganisms (Ahn et al. 2014). Cabezas et al. (2015) stated that when an electric current is generated, there is a change in microorganisms' composition. PMFC generally uses plants that live in water as a medium to cultivate microorganisms that play a role in degrading organic material into electrical energy. However, currently, studies on the use of this technique are undergoing development to enable the use of plants that live in water and dry and semi-arid environments. According to Tapia et al. (2017), PMFC can be applied using plants that live in semi-arid environments, however, the electrical energy output obtained is still lower than the use of plants that live in water. The tubular reactor design applied in this study is still not optimal due to the possibility of oxygen at the anode. Meanwhile, microorganisms' metabolism in degrading organic material takes place anaerobically where there is no oxygen in these conditions. Until now, many further developments regarding PMFC have been carried out in order to obtain increasingly optimum performance. This has been conducted on several aspects that affect PMFC performance, such as the reactor design and the biological components involved. Bombelli et al. (2013) stated that there are still many aspects of PMFC that need to be improved in the future, such as the electrodes' reaction rate, its incorporation to the rhizosphere in plants, the interaction of microorganisms against root exudates, etc.

\section{Conclusion}

PMFC which utilize water hyacinths can produce bioelectricity because they can grow rapidly and facilitate electricity production in PMFCs. Variations in the type of electrodes and the spacing were investigated to determine the correct PMFC configuration. Furthermore, the highest voltage and current density at stable conditions were obtained at $244.8 \mathrm{mV}$ and $185.4 \mathrm{~mA} / \mathrm{m}^{2}$, respectively, with the use of zinc as the anode with a distance of $10 \mathrm{~cm}$ between the electrodes. The maximum PMFC power output produced in this study is $100.2 \mathrm{~mW} / \mathrm{m}^{2}$, with higher yields compared to those that use iron or carbon felt as anode material. The small distance between the electrodes affects the mobility of the protons from anode to the 
cathode, as well as the $\mathrm{pH}$ of the media. Also, the growth of water hyacinth biomass was fast for 30 days, with an average mass growth of $142 \%$ of the initial mass, which indicates that water hyacinth has a high potential of being used in PMFC.

\section{Acknowledgments}

The authors are grateful to the Chemical Engineering Department, Pertamina University, and Chemical Engineering Department, Institute Technology Indonesia, for supporting this research.

\section{References}

Aghababaie, M., Farhadian, M., Jeihanipour, A., \& Biria, D. (2015). Effective factors on the performance of microbial fuel cells in wastewater treatment - a review. Environmental $\begin{array}{llll}\text { Technology } & \text { Reviews, } & 4(1), & 71-89 .\end{array}$ doi:10.1080/09593330.2015.1077896

Ahn, J. H., Jeong, W. S., Choi, M. Y., Kim, B. Y., Song, J., \& Weon, H. Y. (2014). Phylogenetic diversity of dominant bacterial and archaeal communities in plant-microbial fuel cells using rice plants. Journal of Microbiologu and Biotechnology, 24, 1707. doi: $10.4014 / \mathrm{jmb} .1408 .08053$

ASM International. Handbook Committee. (1990). ASM handbook (Vol. 19). Asm International.

Azri, Y. M., Tou, I., Sadi, M., \& Benhabyles, L. (2018). Bioelectricity generation from three ornamental plants: Chlorophytum comosum, Chasmanthe floribunda and Papyrus diffusus. International Journal of Green Energy, 15(4), 254-263. doi: 10.1080/15435075.2018.1432487

Bhatt, V. (2016). Thermodynamics and Kinetics of Complex Formation. In Essentials of Coordination Chemistry (pp. 111137). Elsevier.

Bimanatya, T. E., \& Widodo, T. (2018). Fossil Fuels Consumption, Carbon Emissions, and Economic Growth in Indonesia. International Journal of Energy Economics and Policy, 8(4), 90-97.

Bombelli, P., Iyer, D. M. R., Covshoff, S., McCormick, A. J., Yunus, K., Hibberd, J. M., ... \& Howe, C. J. (2013). Comparison of power output by rice (Oryza sativa) and an associated weed (Echinochloa glabrescens) in vascular plant bio-photovoltaic (VP-BPV) systems. Applied microbiology and biotechnology, 97(1), 429-438. doi: 10.1007/s00253-012-4473-6

Cabezas, A., Pommerenke, B., Boon, N., \& Friedrich, M. W. (2015). G eobacter, A naeromyxobacter and A naerolineae populations are enriched on anodes of root exudate-driven microbial fuel cells in rice field soil. Environmental Microbiology Reports, 7(3), 489-497. doi: 10.1111/17582229.12277

Christwardana, M., Hadiyanto, H., Motto, S. A., Sudarno, S., \& Haryani, K. (2020). Performance evaluation of yeast-assisted microalgal microbial fuel cells on bioremediation of cafeteria wastewater for electricity generation and microalgae biomass production. Biomass and Bioenergy, 139, 105617. doi: 10.1016/j.biombioe.2020.105617

Di, L., Li, Y., Nie, L., Wang, S., \& Kong, F. (2020). Influence of plant radial oxygen loss in constructed wetland combined with microbial fuel cell on nitrobenzene removal from aqueous solution. Journal of Hazardous Materials, 394, 122542. doi: 10.1016/j.jhazmat.2020.122542

Dubey, R., \& Guruviah, V. (2019). Review of carbon-based electrode materials for supercapacitor energy storage. Ionics, 25(4), 1419-1445. doi: 10.1007/s11581-019-02874-0

Gaurav, G. K., Mehmood, T., Cheng, L., Klemeš, J. J., \& Shrivastava, D. K. (2020). Water hyacinth as a biomass: A review. Journal of Cleaner Production, 122214. doi: 10.1016/j.jclepro.2020.122214
Gómora-Hernández, J. C., Serment-Guerrero, J. H., Carreño-deLeón, M. C., \& Flores-Alamo, N. (2020). Voltage production in a plant microbial fuel cell using Agapanthus Africanus. Revista Mexicana de Ingeniería Química, 19(1), 227-237. doi: 10.24275/rmiq/IA542

Hadi, A., Inubushi, K., Furukawa, Y., Purnomo, E., Rasmadi, M., \& Tsuruta, H. (2005). Greenhouse gas emissions from tropical peatlands of Kalimantan, Indonesia. Nutrient Cycling in Agroecosystems, 71(1), 73-80. doi: 10.1007/s10705-004-0380-2

Helder, M., Strik, D. P., Hamelers, H. V., \& Buisman, C. J. (2012). The flat-plate plant-microbial fuel cell: the effect of a new design on internal resistances. Biotechnology for Biofuels, 5(1), 70. doi:10.1186/1754-6834-5-70

Helder, M., Strik, D. P., Timmers, R. A., Raes, S. M., Hamelers, H. V., \& Buisman, C. J. (2013). Resilience of roof-top plantmicrobial fuel cells during Dutch winter. Biomass and Bioenergy, 51, 1-7. doi:10.1016/j.biombioe.2012.10.011

Kauffman, G. B. (1988). The Bronsted-Lowry acid base concept. Journal of Chemical Education, 65(1), 28. doi: 10.1021/ed065p28

Koo, B.-. J., Adriano, D. C., Bolan, N. S., \& Barton, C. D. (2005). Root Exudates and Microorganisms. In Encyclopedia of Soils in the Environment (pp. 421-428). Elsevier.

Kudke, M., Shinde, A. A., \& Saptarshi, S. (2017). Green Electricity Production from Living Plant and Microbial Fuel Cell. International journal of Advance Research in Science and Engineering, 6, 459-466

Liu, H. (2008). Microbial Fuel Cell: Novel Anaerobic Biotechnology for Energy Generation from Wastewater. In S. K. Khanal (Ed.), Anaerobic Biotechnology for Bioenergy Production (pp. 221-246). Wiley-Blackwell. https://doi.org/10.1002/9780813804545.ch10

Logan, B. E., Hamelers, B., Rozendal, R., Schröder, U., Keller, J., Freguia, S., Aelterman, P., Verstraete, W., \& Rabaey, K. (2006). Microbial Fuel Cells: Methodology and Technology $\dagger$. Environmental Science \& Technology, 40(17), 5181-5192. doi:10.1021/es0605016

Lott, M. C., Pye, S., \& Dodds, P. E. (2017). Quantifying the coimpacts of energy sector decarbonisation on outdoor air pollution in the United Kingdom. Energy Policy, 101, 42-51. doi: 10.1016/j.enpol.2016.11.028

Lu, G. W., \& Gao, P. (2010). Emulsions and Microemulsions for Topical and Transdermal Drug Delivery. In Handbook of NonInvasive Drug Delivery Systems (pp. 59-94). Elsevier.

Md Khudzari, J., Gariépy, Y., Kurian, J., Tartakovsky, B., \& Raghavan, G. S. V. (2019). Effects of biochar anodes in rice plant microbial fuel cells on the production of bioelectricity, biomass, and methane. Biochemical Engineering Journal, 141, 190-199. doi: 10.1016/j.bej.2018.10.012

Neina, D. (2019). The Role of Soil pH in Plant Nutrition and Soil Remediation. Applied and Environmental Soil Science, 2019, 1-9. https://doi.org/10.1155/2019/5794869

Novikov, D., Molodkina, L., Chusov, A., \& Vedmetskii, Y. (2015). Electrokinetic and Electroconductivity Properties of Filtering Material Aqualat. Procedia Engineering, 117, 264-272. doi:10.1016/j.proeng.2015.08.161

Pamintuan, K. R. S., Gonzales, A. J. S., Estefanio, B. M. M., \& Bartolo, B. L. S. (2018). Simultaneous phytoremediation of Ni $2+$ and bioelectricity generation in a plant-microbial fuel cell assembly using water hyacinth ( Eichhornia crassipes ). IOP Conference Series: Earth and Environmental Science, 191, 012093. doi: 10.1088/1755-1315/191/1/012093

Park, J., Dilasari, B., Kim, Y., Kim, K., Lee, C. K., \& Kwon, K. (2014). Passivation Behavior and Surface Resistance of Electrodeposited Nickel-Carbon Composites. Electrochemistry, $\quad$ 82(7), 561-565. doi:10.5796/electrochemistry.82.561

Prasad, J., \& Tripathi, R. K. (2018). Scale up sediment microbial fuel cell for powering Led lighting. International Journal of Renewable Energy Development, 7(1), 53. doi:10.14710/ijred.7.1.53-58

Reddy, T. B. (2011). Linden's handbook of batteries (Vol. 4). New York: Mcgraw-hill. 
Citation: Widharyanti, I.D., Hendrawan, M.A., Christwardana, M. (2021). Membraneless Plant Microbial Fuel Cell using Water Hyacinth (Eichhornia crassipes) for Green Energy Generation and Biomass Production. Int. Journal of Renewable Energy Development, 10(1), 71-78, doi: 10.14710/ijred.2021.32403

$\mathrm{P}$ a g e 178

Sangeetha, T., \& Muthukumar, M. (2013). Influence of electrode material and electrode distance on bioelectricity production from sago-processing wastewater using microbial fuel cell. Environmental Progress \& Sustainable Energy, 32(2), 390395. doi:10.1002/ep.11603

Sarma, P. J., \& Mohanty, K. (2018). Epipremnum aureum and Dracaena braunii as indoor plants for enhanced bio-electricity generation in a plant microbial fuel cell with electrochemically modified carbon fiber brush anode. Journal of bioscience and bioengineering, 126, 404-410. doi: 10.1016/j.jbiosc.2018.03.009

Shahbaz, M., Hye, Q. M. A., Tiwari, A. K., \& Leitão, N. C. (2013). Economic growth, energy consumption, financial development, international trade and CO2 emissions in Indonesia. Renewable and Sustainable Energy Reviews, 25, 109-121. doi:10.1016/j.rser.2013.04.009

Takanezawa, K., Nishio, K., Kato, S., Hashimoto, K., \& Watanabe, K. (2010). Factors affecting electric output from rice-paddy microbial fuel cells. Bioscience, biotechnology, and biochemistry, 74(6), 1271-1273. doi:10.1271/bbb.90852

Tapia, N. F., Rojas, C., Bonilla, C. A., \& Vargas, I. T. (2017). Evaluation of Sedum as driver for plant microbial fuel cells in a semi-arid green roof ecosystem. Ecological Engineering, 108, 203-210. doi:10.1016/j.ecoleng.2017.08.017

Timmers, R. A., Strik, D. P. B. T. B., Hamelers, H. V. M., \& Buisman, C. J. N. (2010). Long-term performance of a plant microbial fuel cell with Spartina anglica. Applied Microbiology and Biotechnology, 86(3), 973-981. doi:10.1007/s00253-010-2440-7

Wetser, K. (2016). Electricity from wetlands: Technology assessment of the tubular Plant Microbial Fuel Cell with an integrated biocathode. Doctoral dissertation, Wageningen University

Wetser, K., Liu, J., Buisman, C., \& Strik, D. (2015). Plant microbial fuel cell applied in wetlands: Spatial, temporal and potential electricity generation of Spartina anglica salt marshes and Phragmites australis peat soils. Biomass and Bioenergy, 83, 543-550. doi:10.1016/j.biombioe.2015.11.006

Wilberforce, T., El-Hassan, Z., Khatib, F. N., Al Makky, A., Baroutaji, A., Carton, J. G., \& Olabi, A. G. (2017). Developments of electric cars and fuel cell hydrogen electric cars. International Journal of Hydrogen Energy, 42(40), 25695-25734. doi:10.1016/j.ijhydene.2017.07.054

Zhang, L. L., \& Zhao, X. S. (2009). Carbon-based materials as supercapacitor electrodes. Chemical Society Reviews, 38(9), 2520-2531. doi:10.1039/B813846J

Zhou, Y., Xu, D., Xiao, E., Xu, D., Xu, P., Zhang, X., Zhou, Q., He, F., \& Wu, Z. (2018). Relationship between electrogenic performance and physiological change of four wetland plants in constructed wetland-microbial fuel cells during nongrowing seasons. Journal of Environmental Sciences, 70, 5462. doi:10.1016/j.jes.2017.11.008 